\title{
FISHES OF LAKE TUMBA (DEMOCRATIC REPUBLIC OF CONGO): EVALUATION OF PRESENT STATUS AND COMPARISONS WITH PREVIOUS STUDIES
}

\author{
Norbert ZANGA ${ }^{1,2}$, Anders WILANDER ${ }^{2 *}$, Bila-Isia INOGWABINI ${ }^{3}$, and Kevin BISHOP² \\ ${ }^{1}$ Environment Department, Faculty of Sciences, University of Kinshasa, DRC
}

${ }^{2}$ Department of Aquatic Sciences and Assessment, Swedish University of Agricultural Sciences Uppsala, Sweden

${ }^{3}$ The Jesuit Loyola University of Congo, Kinshasa, DRC

Zanga N., Wilander A., Inogwabini B.-I., Bishop K. 2019. Fishes of Lake Tumba (Democratic Republic of Congo): Evaluation of present status and comparisons with previous studies. Acta Ichthyol. Piscat. 49 (4): 341-354.

Background. Lake Tumba with a surface area of $830 \mathrm{~km}^{2}$ is very humic $(\mathrm{pH}=3.6-4.6)$. The fishery is important for the riparian population but there are concerns about overfishing. The objective of this study was to assess changes in the fish species composition by comparing the presently reported survey (2005-2010) with earlier studies carried out in 1938-1939, 1955-1956, and 1959 Our hypothesis was that Lake Tumba had been overfished. Materials and methods. Fishing was done in the pelagial with gillnet (25 and $30 \mathrm{~mm})$ and line with hooks at three sites within 166 days in 2005-2006 and 2009-2010.

Results. A total of 40 species were identified. Five species were caught all years and at all sites, namely Chrysichthys cranchii (Leach, 1818), Chrysichthys ornatus Boulenger, 1902, Chrysichthys punctatus Boulenger, 1899, Mormyrops anguilloides (Linnaeus, 1758), and Tylochromis lateralis (Boulenger, 1898). Twelve species were only caught once. Weight Per Unit Effort (WPUE) differed with site and season: ranging from 0 to $4200 \mathrm{~g}$. day $^{-1}$ and the Number of fish Per Unit Effort (NPUE) varied from 0 to 27 fishes $\cdot$ day $^{-1}$.

Conclusions. Out of 49 pelagic species caught by Matthes in 1959, we considered five as diminished in numbers or even missing. This may be attributed to high fishing pressure. The protected site Mabali hosted the majority of previously reported species of which two were noted in Matthes's list but not caught by him. Many parameters demonstrated a "positive" difference between Mabali (which is protected from fishing) and the other sites. This site should be a reference area for future monitoring if its status can be maintained. A trend in the fishery based on interviews with fishers indicated a change from larger species to smaller. This was deemed a result of fishing pressure and nine species were identified as diminishing. The presently reported survey introduced quantitative aspects while earlier studies were qualitative. This impairs the ability to draw strong conclusions about overfishing and other anthropogenic activities. The threat of overfishing calls for the need for consistent quantitative monitoring of the fish population, including monitoring of waters in the drainage area, to enable assessment of impact of anthropogenic pressure.

Keywords: historical comparisons, FishBase comparisons, length-weight, NPUE, humic water

\section{INTRODUCTION}

Lake Tumba has a surface area of $830 \mathrm{~km}^{2}$ and is a part of the COMIFAC's (Commission des Forêts d'Afrique Centrale) highest conservation priority landscapes and it is part of the official Lac Tele-Lac Tumba Landscape, where the primary conservation interest is the freshwater ecosystem (Anonymous 2019). There is a scientific station at Mabali within a forest reserve maintained to test the potential for the regeneration of logged forests.

The water of Lake Tumba is extremely acid, with humic acids colouring the water deep brown (median colour value of $130 \mathrm{Pt} \mathrm{mg} \cdot \mathrm{L}^{-1}$ ) and resulting in $\mathrm{pH}$ values below 5 . This results in a low Secchi depth $(<1 \mathrm{~m})$, which severely limits phytoplankton production and, as a result, also fish productivity (Karlsson et al. 2009). Marlier (1958) found that both phyto and zooplankton were scarce in the lake and noted that the benthic fauna also was scarce. The bottom sediment was dominated by kaolin with little particulate organic matter. This indicated an oligotrophic status of the lake. He further noted that the littoral zone often contained limonite and in wind-sheltered parts could be swampy, favourable for littoral fauna, a source for allochthonous material that can serve as a direct or indirect food for the pelagic fishes. Most probably the lake is dominated by an allochthonous food chain based on a flooded drainage area rich in insects and plant litter (Batzer 1998) from

* Correspondence: Dr Anders Wilander, Institutionen för vatten och miljö, Sveriges Lantbruksuniversitet, Box 7050, S-75007 Uppsala, Sweden, phone: +46 706930751, fax:+4618673156, e-mail: (AW) anders.wilander@slu.se, (NZ) zanganorbert@gmail.com, (BII)bila_inogwabini@biari.brown.edu, (KB)kevin.bishop@slu.se. 
which humic substances leach supporting heterotrophic bacteria and few zooplankters (Marlier 1958). The water has a high concentration of dissolved organic carbon (DOC maximum $40 \mathrm{mg} \cdot \mathrm{L}^{-1}$ ). According to Kalff (2002) "wet tropical lakes" have a median DOC concentration of $6 \mathrm{mg} \cdot \mathrm{L}^{-1}$, with a range of $2-30 \mathrm{mg} \cdot \mathrm{L}^{-1}$, which makes Lake Tumba an outlier.

The open lake, together with the surrounding swamps and seasonally inundated forests, is an important fishery resource. Fish are vital both for the diet of the riparian people as well as for marketing. In the eastern part of the Lake Tumba-Lake Tele Landscape, $83 \%$ of all households (approximately 2 million people) were engaged in the fishery in 2005 (Anonymous 2006). An expanding population with an internal population growth of 3.8 percentage points per year creates an increasing pressure on the fish resources. Trans-migrant fishers from locations outside of the Lake Tumba Landscape further add to this pressure. The land use around Lake Tumba was examined by Milton (2015) using Landsat imagery. She found that there was a mosaic of deforestation adjacent to communities around the lake. The increase was 0.8 percentage points per decade in the area, mainly slash and burn, sometimes along the lakeshore. Seasonally inundated forests and swampy areas, however, do not seem to be affected, so this was not considered as a serious direct threat to the fish in Lake Tumba. In the future though, increased logging and agriculture can be anticipated to influence the lake more extensively.

The first detailed fish fauna of Lake Tumba was published by Poll (1942), covering 60 specimens collected within 1938-1939 and deposited at the Royal Museum for Central Africa (RMCA). In October 1955 and June 1956 Marlier (1958) fished near Mabali and listed 33 species caught in the lake pelagial. Matthes (1964) performed an intensive study in August and September 1959 and recorded a total of 119 species. Of these, 49 were assumed to come from Lake Tumba pelagial while the rest from tributaries and swamp forests. Matthes's (1964) work remains the prime reference for this region and moreover includes descriptions about food, reproduction and habitat (including seasonally inundated forests, tributaries and swamps). Among the works, we also considered in our paper, was an interview study with fishers regarding changes in fish species (Akwah and Yoko unpublished*).

Anonymous (2019) stated that there is a general lack of enforcement for fishery regulations and indicated the gravity of the situation: "current fish stock is inadequate for the area". Degradation of aquatic biodiversity and productivity of the lake was assumed to have occurred based on an interview study with fishers (Akwah and Yoko unpublished). However, Béné et al. (2007) noted that "very little solid information existed about the status of Lake Ntomba's [Tumba's] resources that could be used as the basis for a management regime", which underlined the importance of studying the Lake Tumba fish and fishery. Béné et al. (2007) also stated that if the resource had declined, it remains to demonstrate that this was due to overfishing and not caused by environmental changes.

The present paper summarizes fish monitoring in Lake Tumba conducted during 2005-2006 and 2009-2010, focusing on the temporal variation in fish species catches at different locations during the study period. Comparisons were made with the situation in 1959 (Matthes 1964) and, in addition, with earlier studies by Poll (1942) and Marlier (1958).

\section{MATERIALS AND METHODS}

Study area. Lake Tumba is located in the province of Équateur and drains north to the Congo River (Fig. 1). It is a shallow lake, with a mean depth of $3 \mathrm{~m}$ and a maximum depth of $6 \mathrm{~m}$ (Matthes 1964). Hydro-meteorological data were obtained from the CREF (Centre de Recherche en Ecologie et de Foresterie) at Mabali, where the water level was recorded every 5 days. Physical and chemical data are presented in Table 1. All water chemistry samples were analysed by the accredited laboratory at the Department of Aquatic Sciences and Assessment, Swedish University of Agricultural Sciences (SLU). Only samples that were analysed within one month from sampling were used, and only parameters, which are known to be acceptably stable, are reported. Area determinations were based on satellite imagery (DEM).

Fishing methods and fish identification. Two gillnets, each 50-m long and 0.5-m high, with two mesh sizes (25 and $30 \mathrm{~mm}$, knot to knot) and the smaller No. 12 hooks were used (except at Mabali in 2005 when No.10 hooks were used). The hooks $(n=100)$ were baited with earthworms and fixed on a $200 \mathrm{~m}$ line, with sinkers at each end. The fishing gears were harvested usually three times (1-5) during a period of $24 \mathrm{~h}$.

In addition to FishBase (Froese and Pauly 2019) many documents were used to enable correct identification of species (Teugels 1986, Teugels et al. 1990, Tshibwabwa and Teugels 1995, Boden et al. 1997, Norris 2002, Geerinckx et al. 2004, Moelants et al. 2014). A visit to the RMCA, Tervuren, Belgium further supported identification with photos.

For each fishing gear, all specimens were identified, weighed (since Oct. 2005), and total length (TL) was measured.

Fishing sites and dates. Three pelagic sites along the eastern shore were fished (Fig. 1). The distance from shore to nets varied between 0.17 and $5.6 \mathrm{~km}$. Mabali is the site most inundated during high water level. Here the watershed was logged and later replanted. The town of Mabali has a population of about 1600 persons and is the headquarters for the surrounding scientific reserve (CREF). Thanks to this reserve, the waters of the Mabali site are protected from fishing. Near Ntondo lies Bikoro (Fig. 1) with a population of ca 13000 inhabitants, a cattle farm, and a nearby tributary to the lake. Ikoko sampling site lies close to a large village by the same name. There, 
the littoral zone is shallow, with a permanent swamp. Nearby are two tributaries that support a large spawning site of Coptodon congica (see Inogwabini et al. 2009).

Sampling sites and the sampling year for Matthes (1964) and the presently reported study are presented in Table 2. Matthes used a large variety of fishing gear: a net (mesh 1.4-7.0 cm), dynamite, electrofishing device, and artisanal methods, both in the lake and tributaries. He also attempted the use seines but found them unusable due to submerged branches and stones. For the presently reported study, fishing was planned to coincide with the rainy and dry seasons, however for evaluation, it was tricky to separate these, therefore water level periods (Fig. 2) were used instead to classify the results.

Data analysis. All scientific names for the three earlier publications were updated based on synonyms in FishBase
(Froese and Pauly 2019). FishBase standard length (SL) values were multiplied by a factor to approximate the total length (TL) for comparison with presently reported values. The median value of 1.2 was used, which was based on 31 FishBase parameters for 21 of the species in Table 3. For Hydrocynus TL $=1.18 \times$ FL was used based on two other Hydrocynus species from FishBase.

As the fishing intensity differed, catches were "normalized" as WPUE (Weight Per Unit Effort: the sum of weight $\cdot$ day $^{-1}$ ) and NPUE (Number of fish Per Unit Effort: the sum of fish $\cdot$ day $^{-1}$ ) calculated for two $50 \mathrm{~m}$ net panels and 100 hooks for $24 \mathrm{~h}$ of fishing. At Mabali four panels were used, thus the effort was recalculated for two panels in correspondence with the other sites.

For statistical calculations, the JMP software*, version 10.0, was used.

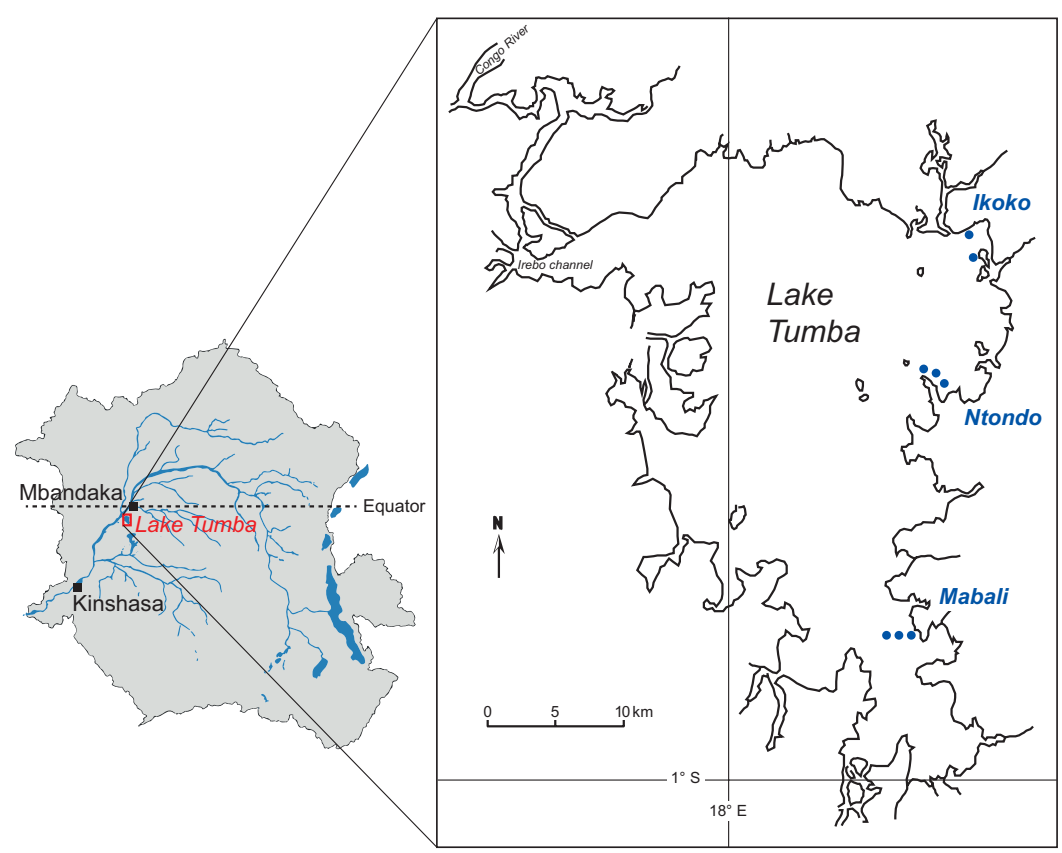

Fig. 1. Maps showing location of Lake Tumba in the Congo River drainage area (Democratic Republic of Congo) and fishing sites (red) superimposed on bathymetric map (Marlier 1958); the map of the drainage area was adapted from Wikipedia

Physical and chemical characteristics of Lake Tumba, Democratic Republic of Congo

Table 1

\begin{tabular}{|c|c|c|c|c|c|c|}
\hline \multirow{3}{*}{ Year studied } & \multirow{3}{*}{$\begin{array}{c}\text { Marlier } 1958 \\
1955-1956\end{array}$} & \multirow{3}{*}{$\begin{array}{c}\text { Dubois } 1959 \\
1955-1956\end{array}$} & \multicolumn{4}{|c|}{ Presently reported study } \\
\hline & & & \multirow[t]{2}{*}{$2005-2010$} & \multicolumn{3}{|c|}{ 2009-2010 } \\
\hline & & & & Min. & Median & Max \\
\hline Lake area $\left[\mathrm{km}^{2}\right]$ & 765 & & $\approx 830$ & & & \\
\hline Lake + inundated area $\left[\mathrm{km}^{2}\right]$ & - & & $\approx 1600$ & & & \\
\hline Drainage area $\left[\mathrm{km}^{2}\right]$ & $7380+765$ & & $\approx 8300$ & & & \\
\hline Elevation above sea level [m] & 350 & & 295 & & & \\
\hline Secchi depth [m] & & $0.75-1.00$ & & 0.6 & 0.8 & 1.0 \\
\hline $\mathrm{pH}$ & & $4.5-4.9$ & & 3.6 & 4.3 & 4.6 \\
\hline Colour $\left[\mathrm{Pt} \mathrm{mg} \cdot \mathrm{L}^{-1}\right]$ & & - & & 90 & 130 & 370 \\
\hline $\mathrm{TOC}\left[\mathrm{mg} \cdot \mathrm{L}^{-1}\right]$ & & - & & 13 & 16 & 40 \\
\hline
\end{tabular}

Colour values calculated from absorbance measurements at $420 \mathrm{~nm}$; TOC $=$ total organic carbon. 
Fishing sites and dates in Lake Tumba, Democratic Republic of Congo (1959-2010)

\begin{tabular}{cllcl}
\hline Year & \multicolumn{1}{c}{ Fishing sites } & \multicolumn{1}{c}{ Months } & Fishing days & \multicolumn{1}{c}{ Reference } \\
\hline 1959 & Bikoro, Mabali IRSAC & Aug-Sept & 24 & Matthes 1964 \\
2005 & Mabali & May-Aug and Oct-Dec & 91 & Presently reported study \\
2006 & Ikoko & Feb & 13 & \\
$2009-2010$ & Ntondo & Jun-Jul and Dec-Jan & 62 & \\
\hline
\end{tabular}

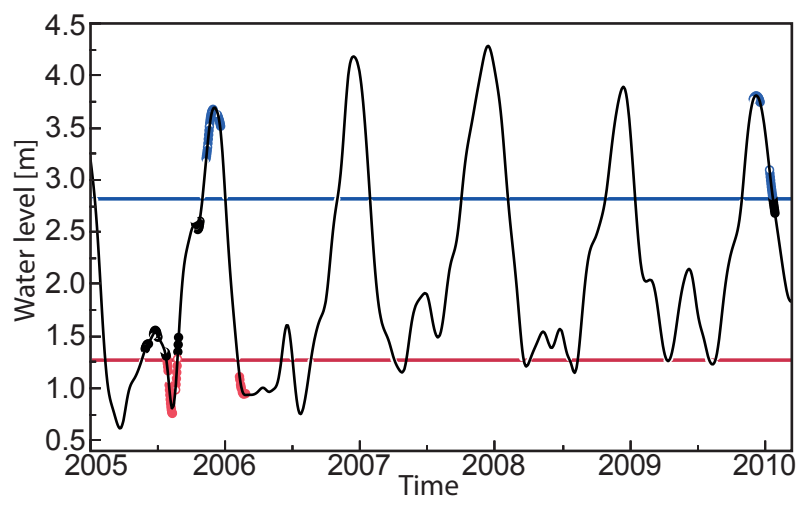

Fig. 2. Water level in Lake Tumba, Democratic Republic of Congo, recorded at Mabali; three selected water level periods are indicated; high $(\geq 2.85 \mathrm{~m})$ in blue, normal $(>1,3-<2.85 \mathrm{~m})$ in black, and low $(\leq 1.3 \mathrm{~m})$ in red; the black line is a spline function based on water level values observed every 5 days; fishing days are marked

\section{RESULTS}

Water level in Lake Tumba. There was a seasonal, bimodal variation in water level with decreasing levels from January through March, followed by a minor increase in May and June. The water level was typically lowest in August, increasing to a maximum, usually in December. Normally the lake drains into the Congo River, but when the river is in flood, $\mathrm{pH}$-circumneutral water flows into the northern part of the lake through the Irebu channel. Water levels during the project period, together with fishing days are shown in Fig. 2.

Fish species and catch. Fishing was done during 166 days (Table 2), in this number 11 without a catch. In total, about 1100 fish specimens were caught. Forty species, representing 14 families, were identified (Table 3). For the five most common species WPUE and NPUE were calculated (Table 4). The most frequent was Chrysichthys cranchii ${ }^{*}$, which had by far the highest NPUE and WPUE values.

pH value. All 40 species were caught live in acid water with a $\mathrm{pH}$ lower than 4.6. Such low $\mathrm{pH}$-vales are very rare in tropical lakes. In the Democratic Republic of Congo (DRC) only Lake Tumba and Mai Ndombe have such low pH levels. In FishBase (Froese and Pauly 2019) some species are noted for requiring higher $\mathrm{pH}$ values and for others values are missing.

Length-weight constants from this study. For three species caught during this study, FishBase did not have length-weight relations. Results from calculations according to equation (1), and fulfilling the criteria listed by Froese et al. (2011) are presented in Table 5.

$$
W=a \times L^{b}
$$

where $W$ is the fish weight ( $\mathrm{g}$ ), $L$ is the length (TL cm), $a$ is the intercept, and $b$ is the slope.

Community structure. Features of the fish population structure could be elucidated based on the numerous fishing times. The number of species caught varied between the sites, amounting to 22 species captured at Ikoko, 29 species at Mabali, and 14 species at Ntondo. The 11 most common species were all caught at Mabali, while at Ntondo as many as six of these were absent. Twenty species were only caught at one site, while 5 at Ikoko, 11 at Mabali, and 5 at Ntondo. A total of 13 species were only caught once, about equally distributed among the sites. The presence of some species, such as Mormyrops anguilloides, varied little between the sites, whereas other species such as Pterochromis congicus and Schilbe tumbanus were caught only at Mabali, which is protected from fishery, and in appreciable numbers.

Effect of water level and site. Comparisons were made for pairs of sites with the same water level period (Table 6). At normal and high-water level Mabali had the highest number of species, NPUE and WPUE. Catches (NPUE and WPUE) were significantly higher at Mabali compared to Ntondo. The total species number was lowest (14) (out of which 11 were pelagic fishes) at high water level, reaching 31 at normal-level waters, and 28 in low-water level. At Ntondo all six species caught during high water level were also caught during normal levels when an additional eight species were also caught. The migration of fish from 


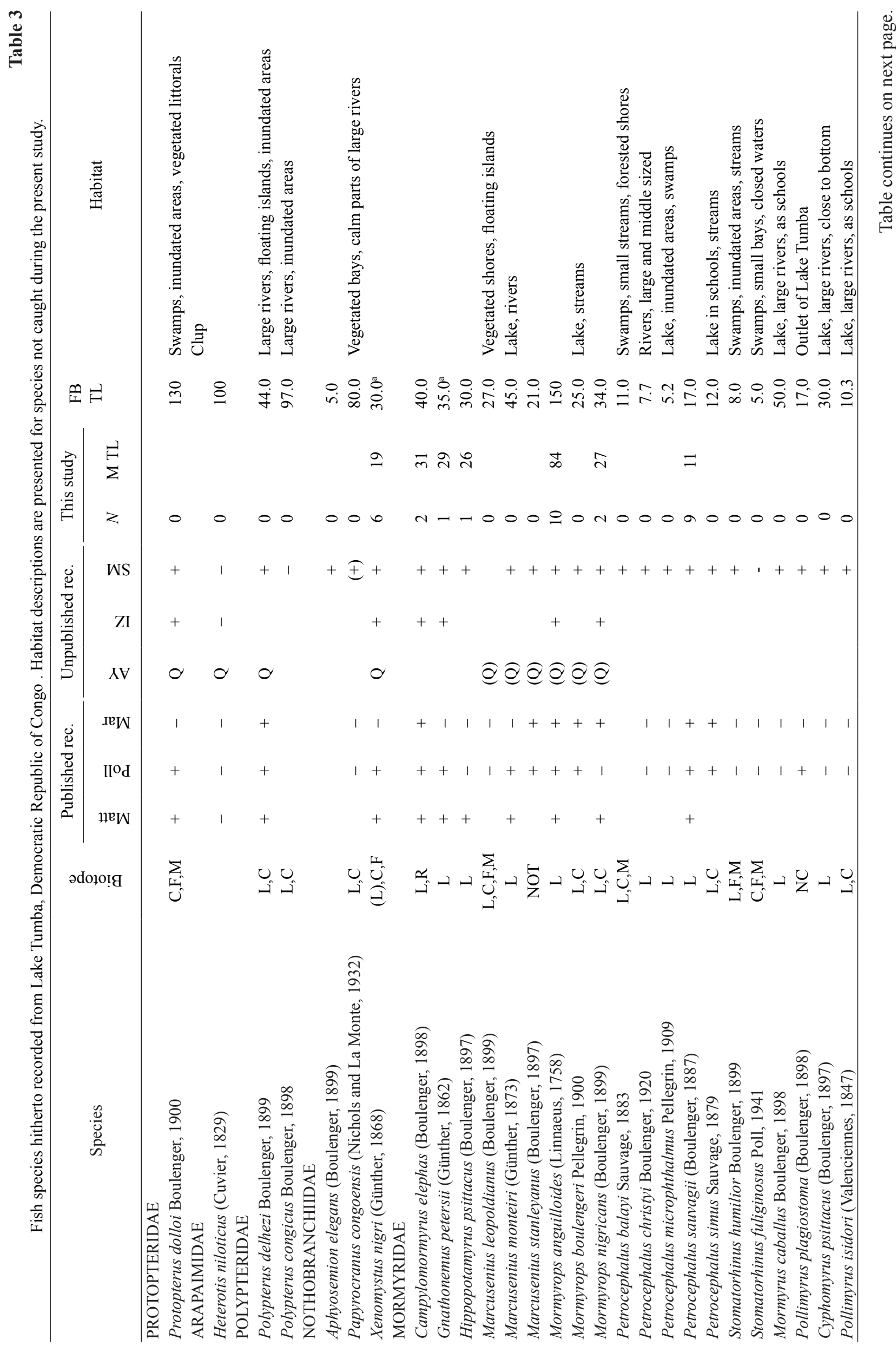




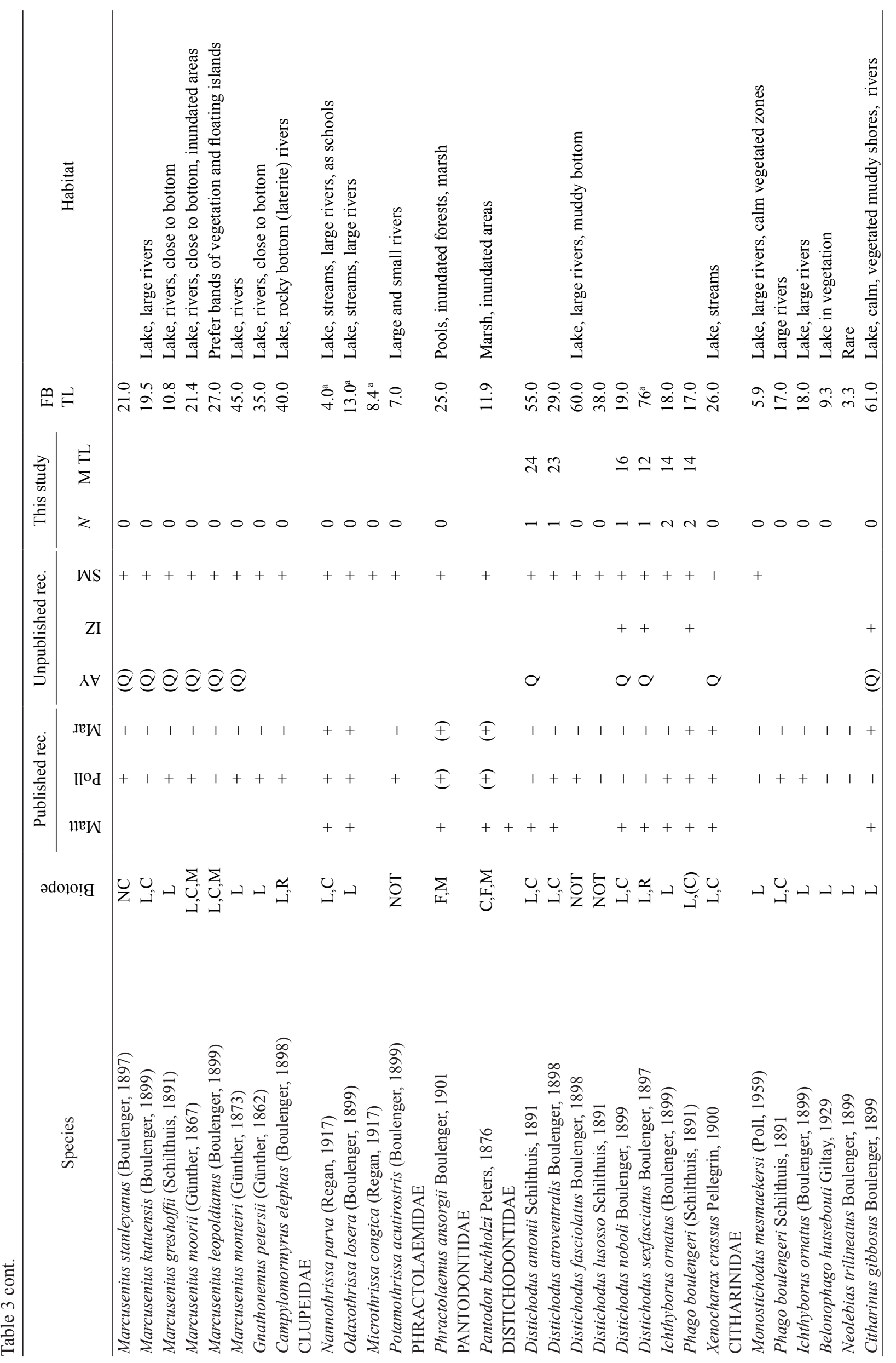




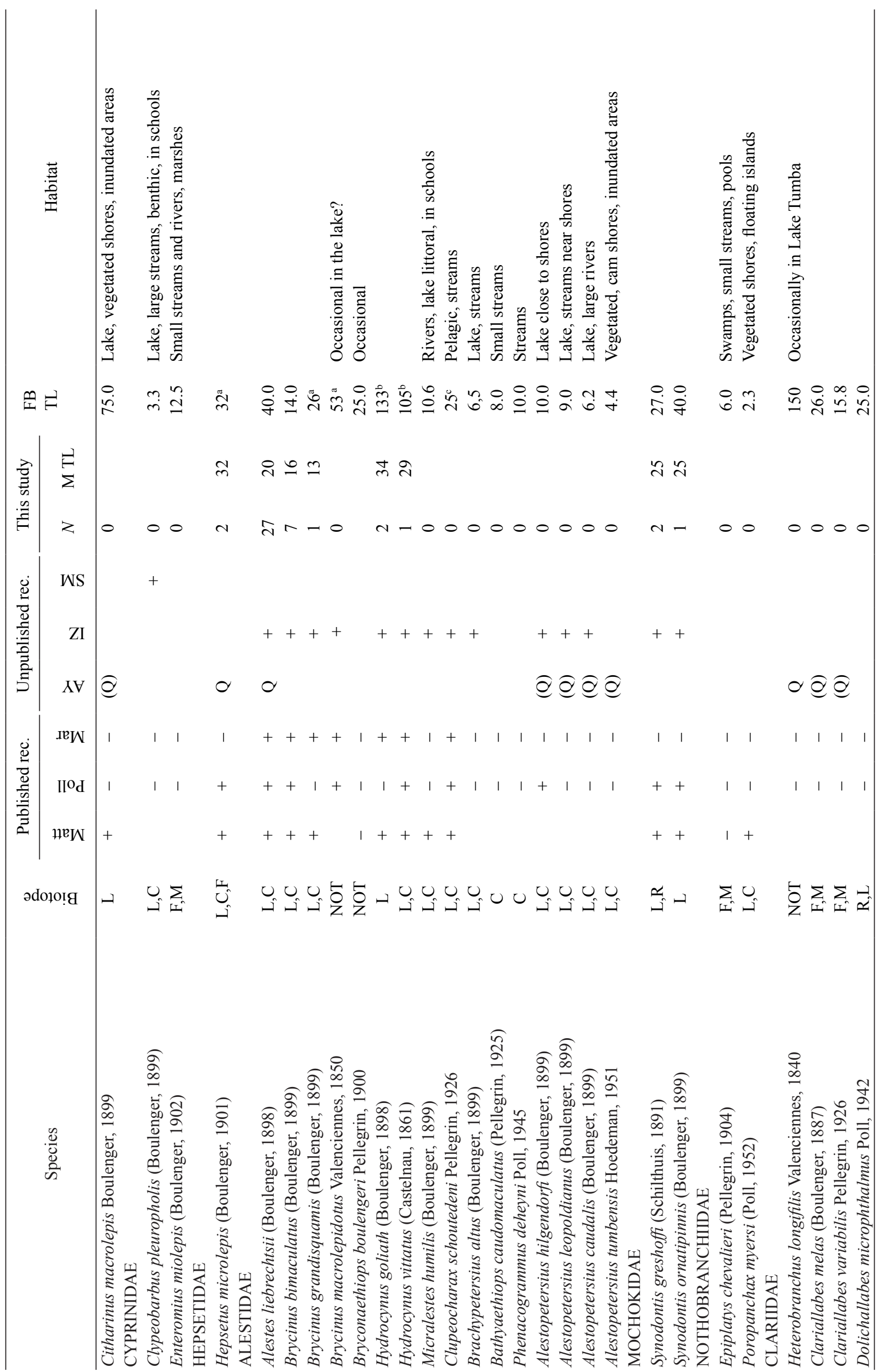




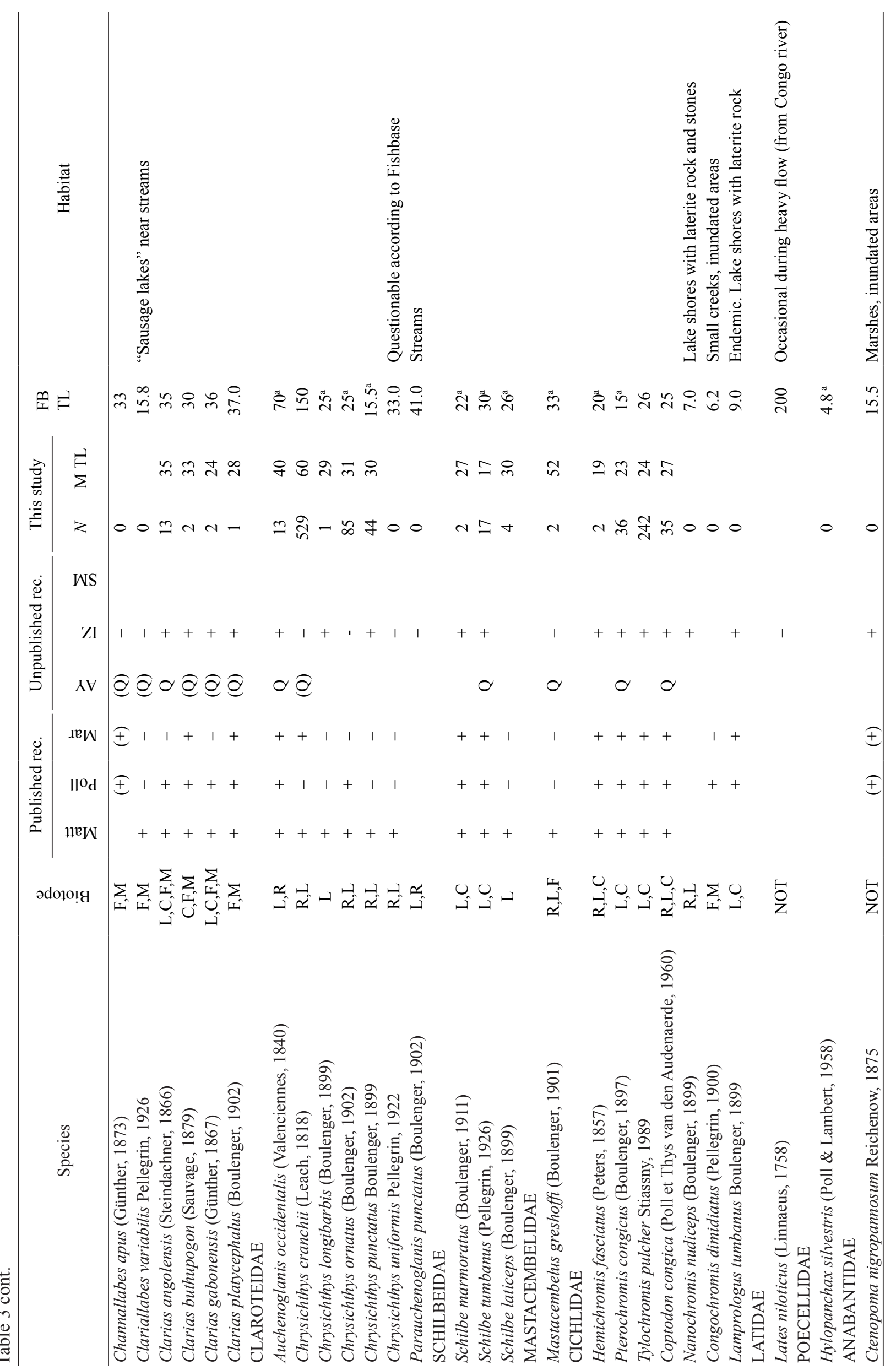


the pelagial to inundated areas during periods of highwater level was evident from the number of species caught at different water levels.

Only the Mabali site was fished during all three water level periods, enabling effects across all water levels to be studied. NPUE was significantly higher $(P<0.001)$ higher during high water than the normal or low water level, while for WPUE there was no significant difference between high and normal water level. Among five common species two had a significantly larger TL at normal and one at low water level. During high water level, none of the five most common species had the largest TL and Pterochromis congicus was even absent, probably due to migration of mature fish to inundated areas. Maximum TL at the sites varied among species: Chrysichthys cranchii was significantly larger $P<0.0001$ at Ntondo, but at Mabali $C$. ornatus was larger (not significantly) and C. punctatus significantly larger $(P<0.05)$.

\section{DISCUSSION}

While the earlier studies by Poll (1942), Marlier (1958), and Matthes (1964) were qualitative, only the presently reported study had a quantitative component. In the present paper, overfishing is defined as a qualitative change in species. Three indicators of possible overfishing or environmental influence were examined:

- Change in species composition compared to previous studies

- Reduced length for caught fish compared to FishBase

- Reduced weight-length values compared to FishBase

Change in species composition. A change in species composition may be caused by overfishing but could also be an artefact due to the different fishing techniques discussed below. The conclusions drawn may be treated as hypotheses. The three available publications about fish species in Lake Tumba: Poll (1942), Marlier (1958), and the most extensive by Matthes (1964) were compared with species caught during this study. Poll (1942) reported 60 species from Lake Tumba found in museum material, collected in 1938 and 1939. Out of these, 55 were confirmed to be present in the DRC by FishBase (Froese and Pauly 2019). According to Matthes's (1964) evaluation, 36 of those noticed by Poll (1942) were deemed to be pelagic species. The others were considered to be caught in the littoral or inundated forest and thus not relevant for comparisons with the presently reported study, which focused on the pelagic zone. The specimens were from two sites, namely one along the east shore (probably Bikoro) and the other one on the SW shore. Marlier (1958) fished with a gillnet in Lake Tumba from Mabali (IRSAC, Institute pour la Recherche Scientifique en Afrique Centrale). He found (as later also Matthes $1964 \mathrm{did}$ ) the use of seines impossible due to rocks and branches in the nearshore water. He caught 28 species, and are also that were pelagic according to Matthes (1964). Matthes (1964) recorded 119 species as being caught in Lake Tumba including tributaries and flooded forests. However, he remarked that he never caught eight of these (with an asterisk in his "Liste des poissons..."). Based on 
Table 4

Number of fish per unit effort (NPUE) and weight per unit effort (WPUE) (mean values) for the five most common fish species $(\mathrm{N}>20)$ within a total of 166 fishing days in Lake Tumba, Democratic Republic of Congo

\begin{tabular}{|c|c|c|c|c|}
\hline Species & $n$ & $N$ & $\begin{array}{c}\text { NPUE } \\
{\left[N \cdot \text { day }^{-1}\right]}\end{array}$ & $\begin{array}{c}\text { WPUE } \\
{\left[\mathrm{kg} \cdot \text { day }^{-1}\right]}\end{array}$ \\
\hline Chrysichthys cranchii & 79 & 529 & 3.20 & 0.250 \\
\hline Chrysichthys ornatus & 50 & 85 & 0.51 & 0.045 \\
\hline Chrysichthys punctatus & 25 & 44 & 0.27 & 0.066 \\
\hline Pterochromis congicus & 22 & 36 & 0.22 & 0.001 \\
\hline Tylochromis lateralis & 40 & 242 & 1.40 & 0.063 \\
\hline
\end{tabular}

$N=$ number of fish caught, $n=$ number of days the given fish was present in catches.

Table 5

Length-weight relations of three fish species from Lake Tumba (Democratic Republic of Congo), which fulfil the requirements given by Froese et al. (2011)

\begin{tabular}{lccccccc}
\hline \multicolumn{1}{c}{ Species } & $N$ & $\begin{array}{c}\text { TL (range) } \\
{[\mathrm{cm}]}\end{array}$ & $a$ & $95 \% \mathrm{CI} a$ & $\log b$ & $95 \% \mathrm{CI} b$ & $r^{2}$ \\
\hline Chrysichthys cranchii & 354 & $7.2-60.0$ & 0.00988 & $0.00831-0.01169$ & 3.008 & $2.946-3.070$ & 0.962 \\
Chrysichthys ornatus & 51 & $9.9-28.0$ & 0.00120 & $0.00316-0.01291$ & 3.131 & $2.895-3.367$ & 0.935 \\
Chrysichthys punctatus & 41 & $7.7-29.6$ & 0.01770 & $0.01161-0.02697$ & 2.289 & $2.609-2.968$ & 0.962 \\
\hline
\end{tabular}

$N=$ number of fishes, $a=$ intercept, $95 \% \mathrm{CI} a=95 \%$ confidence intervals of $a, b=$ slope, $95 \% \mathrm{CI} b=95 \%$ confidence intervals of $b$; $r^{2}=$ coefficient of determination.

information in his table column headed "Biotope" and in his text "Notes biologiques" about habitat, fishing sites, and methods, some 49 species were judged to have the pelagial as habitat. The remaining species were thus assumed to inhabit the littoral, tributaries, wetland and/or flooded forest which were waters not sampled during the presently reported study. Pollimyrus plagiostoma (Boulenger, 1898) found by Matthes (1964) at the outlet (Irebu) was also excluded as this probably entered this part of the lake with neutral water from the Congo River, a phenomenon known to sporadically carry species from the Congo River to the northernmost part of Lake Tumba. Such species remigrate to the Congo River when the flow reverts. In 2005 Inogwabini and Zanga (unpublished*) caught 30 species in Lake Tumba. Stiassny and Mamonekene (unpublished ${ }^{* *}$ ) and stated that as many as 152 species have been found in the lake and its tributaries. They based their table for Lake Tumba fishes on Brooks et al. (2011). However, that publication does not have a printed list of species. Table 3 only presents species from confirmed lake sites.

During the pelagial fishing by the presently reported study in Lake Tumba, 40 species were found. This was nine species fewer than the number of species Matthes (1964) noted to be pelagic (L) (Table 7). Since the fishing gear used by Matthes (1964) and during the presently reported study differed, there is a reason to attempt an evaluation of differences in species caught. The fishing gears used in the presently reported study were more limited than those used by Matthes (1964), who used a wider range of mesh sizes. Thus, some of Matthes's species were unlikely to have been caught this time even if they were present. Nannothrissa parva was not caught most likely due to its small size (TL). So was also the case for Clupeocharax schoutedeni (with a corrected TL value). Furthermore, a check of the Matthes (1964) "Habitat" paragraph indicated that some of these species were, in fact, littoral or mainly living in streams. That is the case for Chrysichthys uniformis, which was not caught by Marlier (1958) (Table 7). He probably only fished in the pelagial. Matthes (1964) caught Micralestes humilis using dynamite and electrofishing and he wrote that it lives in streams and the littoral zone. Even this species was not caught by Marlier (1958). Matthes (1964) used gillnets (smallest mesh $1.4 \mathrm{~cm}$ ) to catch Odaxothrissa losera with a SL 9.0 to $9.4 \mathrm{~cm}$. In "Habitat" he, apart from lakes, also mentioned rivers and streams. In our study, only 51 specimens representing three species with a TL $\leq$ $9.0 \mathrm{~cm}$ were caught, mostly Chrysichthys cranchii and C. punctatus. These were caught with a hook. According to Matthes (1964), these two are carnivores. Odaxothrissa losera is considered "petit carnassier" and thus possibly attracted by the baited hook. However, all information suggests that this species is not pelagic and too small to be caught by net, but we still consider it as missing. The largest fish caught in the presently reported study was an 84-cm specimen of Mormyrops anguilloides (FishBase $\max$. TL $150 \mathrm{~cm}$ ). Thus, all large species in Table 7 should have been possible to catch 2005-2010. Among the "remaining" five species Matthes (1964) judged two as rare and the additional three as common/abundant. The difficulty to evaluate previous presence is supported by the fact that Matthes (1964) never caught Brycinus macrolepidotus, but since it was noted by both Poll (1942) and Marlier (1958) it is considered as missing from the

\footnotetext{
* See footnote on page 349

** See footnote on page 349 .
} 
lake now. Summing up, in spite of the intensive fishing during this study, five species that could have been caught (based on size and pelagial habitat) were not caught and thus deemed as having been impacted by intensive fishing (Table 7). However, these five species are not considered as absent only rare (Kutshukina and Micha 2013). One of these missing species, however, Micralestes humilis was identified in the interview study by Akwah and Yoko (unpublished $^{*}$ ) as increasing.

Maximum total length. Fish species, which were shorter than expected according to FishBase (Froese and Pauly 2019) could indicate overfishing. A smaller size could, however, also be due to poor food availability (Karlsson et al. 2009) in the acidic and nutrient-poor (oligotrophic) pelagial. Rochet et al. (2003) considered mean length an operational indicator of the effects of fishing on

Table 6

Basic parameters related to fish catching at respective sampling sites in Lake Tumba, Democratic Republic of Congo

\begin{tabular}{cccccc}
\hline \multirow{2}{*}{ Parameter } & Water & \multicolumn{5}{c}{ Site } & \multirow{2}{*}{$P$} \\
\cline { 3 - 5 } & level & Ikoko & Mabali & Ntondo & \\
\hline Fishing days & $\mathrm{H}$ & - & 30 & 29 & \\
& $\mathrm{~N}$ & - & 41 & 33 & \\
& $\mathrm{~L}$ & 13 & 20 & - & \\
\hline Species & $\mathrm{H}$ & - & 13 & 6 & \\
& $\mathrm{~N}$ & - & 23 & 14 & \\
& $\mathrm{~L}$ & 22 & 16 & - & \\
\hline NPUE & $\mathrm{H}$ & - & 12 & 3 & $<0.001$ \\
& $\mathrm{~N}$ & - & 4 & 2 & $<0.01$ \\
& $\mathrm{~L}$ & 7 & 6 & - & \\
\hline WPUE & $\mathrm{H}$ & - & 0.58 & 0.41 & $<0.01$ \\
& $\mathrm{~N}$ & - & 0.44 & 0.18 & $<0.001$ \\
& $\mathrm{~L}$ & 0.35 & $(0.23)$ & - & \\
\hline
\end{tabular}

NPUE and WPUE values are median; $\mathrm{H}=$ high water level, $\mathrm{N}=$ normal water level, $\mathrm{L}=$ low water level; Wilcoxon significance. WPUE data for Mabali at low water level incomplete data a population level. They point out the challenges of finding a reference value. Here one possibility was to use FishBase TL values as a reference. Out of the 40 species caught in the presently reported study, 11 species had a measured quotient max TL/max FishBase TL $>1$, thus, a larger TL than that found in FishBase. Of 11 species with $\geq 9$ fishes Alestes liebrechtsii, Petrocephalus sauvagii, and Schilbe tumbanus had a measured max TL/max FishBase TL between 0.49 and 0.65 , thus shorter than "standard" according to Welcomme (1999). For three other species (Auchenoglanis occidentalis, Chrysichthys cranchii, and Mormyrops anguilloides) with a FishBase TL $\geq 60 \mathrm{~cm}$ a low quotient (0.4-0.56) might indicate overfishing, but the small net mesh used is more likely to be the cause. Among others, Kantoussan et al. (2009) considered the use of size-based spectra as a better tool for assessing possible effects of overfishing. Such a spectrum may be calculated for Lake Tumba from the presently reported data, but no reference spectra were found for such an evaluation.

Fish weight values. In FishBase (Froese and Pauly 2019) three species caught in this study have constants for length-weight relations according to Equation 1. Based on these constant values and measured fish length (TL) a fish weight was calculated and compared with measured weight. In total only 2 calculations were possible for Hydrocynus vittatus, 10 for Mormyrops anguilloides, and 12 for Parachanna obscura. A quotient $<1$ indicates a leaner body than the reference value. Quotients for $H$. vittatus were one on each side of 1 . With several alternative calculations, all values for $M$. anguilloides and P. obscura gave a lower weight than expected from these equations (max. quotients 0.58 and 0.93 , respectively). This is likely due to poor nourishment, an effect of the low food availability in the humic lake (Karlsson et al. 2009). Change in fish catches. An important contribution to the understanding of the fishery in Lake Tumba is the work by Akwah and Yoko (unpublished*), who interviewed fishers around the lake. They presented a table with the changes perceived for 38 fish species as identified by

Table 7

The nine pelagic (L) species caught by Matthes (1964) from Lake Tumba (Democratic Republic of Congo) but not during presently reported study

\begin{tabular}{lccl}
\hline \multicolumn{1}{c}{ Species } & FishBase TL [cm] & Matthes SL [cm] & \multicolumn{1}{c}{ Matthes description } \\
\hline Brycinus macrolepidotus & 53 & NC & Rare \\
Chrysichthys uniformis & 33 & 32 & Rather common \\
Clupeocharax schoutedeni & $25 \mathrm{M}$ & 3.0 & Common, but sporadic \\
Marcusenius monteiri & 45 & 29 & Very common \\
Marcusenius stanleyanus & 21 & - & Rare \\
Micralestes humilis & 10.6 & $2.3-6.6$ & Abundant \\
Nannothrissa parva & 4 & $2.0-4.2$ & Abundant \\
Odaxothrissa losera & 13 & $9.0-9.4$ & Common \\
Xenocharax spilurus & 26 & $6.0-26$ & Abundant \\
\hline
\end{tabular}

Species not caught, but potentially available for the gear used are marked in bold; NC = species noted but not caught by Matthes (1964), M $=$ the FishBase value of $25 \mathrm{~cm}$ is most likely a mistake; Matthes (1964) provides SL of $3.0 \mathrm{~cm}$ and Marlier (1958) shows a drawing of the species with an estimated length of $2.5 \mathrm{~cm}$. 
vernacular names. The scientific names were found for the majority of species based on Matthes's (1964) list of vernacular and scientific names. However, in Akwah and Yoko (unpublished*) the tendency was ambiguous for some species leaving 25 on which to base an assessment of trends in catches (see Table 3).

Nine species were noted by Akwah and Yoko (unpublished $^{*}$ ) as decreasing. All of them were caught by Matthes (1964) and five of these were caught in this study (Table 8). These had a FishBase TL 19-75 cm (Froese and Pauly 2019). Out of the nine "decreasing species" (Akwah and Yoko unpublished*), six were considered pelagic and thus possible to have been caught in the 2005-2010 survey. The presently reported study failed to catch four of these "decreasing species", which were all specified by Matthes (1964) as common lake species. However, his "Habitat" sentences in the text state that C. gibbosus prefers vegetated shores and $C$. macrolepis prefers the littoral. Both of these Citharinus species and Xenocharax spilurus have a compressed shape, which makes them unlikely to be caught with the net meshes used. They are also pelophages/phytophages, so not attracted by baited hooks. In conclusion, the presently reported absence of these three species and the small number caught of an additional four species support the assumption of their decline (except for Clarias angolensis) as identified by the interviews, even if there are reasons why our pelagic fishing may have missed these even if they were present. Already Marlier (1958) noted that fishery of Citharinus was extremely productive but appeared to be in decline.

Fishers reported increasing catches of 16 identified species out of which 6 were not caught by us (Table 9). Protopterus dolloi was included in the report of Matthes (1964), but not caught by him. Two of these species are small (FishBase TL $<10 \mathrm{~cm}$ ) and unlikely to be caught during the presently reported study due to the net mesh size. The other species were noted by Matthes (1964) in his "Habitat" descriptions as living in streams and/or swamps and thus not in the pelagial. Thus, the absence of all these species in this study is not inconsistent with the report of increasing catches. Interesting is the reported increase of Heterotis niloticus. It was introduced to the aquaculture in 1950 in the Ubangi River, a right-bank tributary to the Congo River, close to the outlet of Lake Tumba (Moreau et al.1988). Welcomme (1988) stated that it escaped and was found in Lake Tumba in 1969 and thus was absent in earlier studies. During periods of high inflow from the Congo River to Lake Tumba, this species is known to occupy non-acid water near the lake outlet, outside of area for presently reported study.

A possible indication of fishing pressure can, however, be found in the difference between the FishBase TL (Froese and Pauly 2019) of species reported by fishers (Akwah and Yoko unpublished*) to be increasing/ decreasing. The group of eight decreasing species had a slightly longer FishBase TL (Wilcoxon $P=0.31$ ). Such a symptom named fishing down (Pauly et al. 1998) would probably be consistent with a fishing pressure impacting larger species e.g., Distichodus antonii, and in parallel a change to increasing fishery of other species e.g., the small Nannothrissa parva. The increased fishery of small fish as N. parva and Micralestes humilis may be a result of the fishing with small-mesh mosquito net since the 1990s (Kutshukina and Micha 2013). Laë (1997) confirmed that fishers prefer to catch large species, generally predators, and when the abundance of these decrease, fishing activities will be diverted towards smaller sized fish, generally herbivores. Welcomme (1999) corroborated this assumption by saying "The main impact of both fishing and environmental degradation is the reduction of mean length of individuals". Pauly et al. (1998) also showed a decline in mean trophic level for inland waters as a sign of unsustainable fishing. They also pointed out that a species would change food while growing (often as young from being herbivore to carnivore) and even then, there may be variation for species depending on available food. Similarly (Allan et al. 2005) stated that multispecies fishing can lead to "fishing down the food

Table 8

Fish species stated by fishers to decrease, Lake Tumba, Democratic Republic of Congo (Akwah and Yoko unpublished*); All species were caught by Matthes (1964)

\begin{tabular}{lcccc}
\hline \multicolumn{1}{c}{ Species } & $\begin{array}{c}\text { Poll } \\
(1942)\end{array}$ & $\begin{array}{c}\text { Marlier } \\
(1958)\end{array}$ & N & CM \\
\hline Clariallabes variabilis $^{\text {Citharinus gibbosus }}$ & - & - & 0 & \\
Citharinus macrolepis & + & - & 0 & \\
Clarias angolensis $^{1}$ & - & - & 0 & \\
Distichodus antonii $^{1}$ & + & - & 13 & $\mathrm{~L}$ \\
Distichodus noboli $^{1}$ & - & - & 1 & $\mathrm{~L}$ \\
Distichodus sexfaciatus $^{1}$ & - & - & 1 & $\mathrm{~L}$ \\
Mastacembelus greshoffi $^{1}$ & - & - & 1 & $\mathrm{~L}$ \\
Xenocharax spilurus $^{1}$ & - & - & 2 & $\mathrm{~L}$ \\
\hline
\end{tabular}

$N=$ Total number of fish caught during the presently reported study (2005-2010), $\mathrm{CM}=$ comments; $\mathrm{L}=$ pelagial: lake habitat (L) according to Matthes (1964).

Table 9

Fish species stated by fishers to increase, Lake Tumba (Democratic Republic of Congo) (Akwah and Yoko unpublished*)

\begin{tabular}{lc}
\hline \multicolumn{1}{c}{ Species } & TL [cm] \\
\hline Channallabes apus & 33.0 \\
Heterotis niloticus & 100.0 \\
Micralestes humilis & 10.0 \\
Nannothrissa parva & 4.2 \\
Polypterus delhzi & 44.0 \\
Protopterus dolloi & 130.0 \\
\hline
\end{tabular}

The fish species listed above (except for Heterotis niloticus) were recorded by Matthes (1964) but not caught during the presently reported study (2005-2010); TL = total length according to FishBase (Froese and Pauly 2019), Habitat = data from the chapter "Expose systematique et notes biologiques" of Matthes (1964). 
web" causing larger species to be replaced by smaller, planktivorous species with a higher productivity. Kolding and van Zwieten (2014) advocated that fishing-down might replace reduced predation with fishing. From a fishery point of view, this is advantageous, since primary consumers have a higher production while larger species are less productive top-predators. This may be happening in Lake Tumba but FishBase Trophic Level data (Froese and Pauly 2019) indicated no difference between decreasing and increasing species. In the neighbouring lake Mai-Ndombe, interviews with fishers by Kutshukina and Micha (2013) found that nine diminishing species had not actually disappeared, but were living in habitats more difficult to access. So even though intensive fishery may reduce the presence of species, fishing is not likely to eradicate fish species in Lake Tumba. Inogwabini (2014) found that the distance to a market was strongly associated with relative fish abundance. This is confirmed by the comparison between Ntondo and Mabali. The former lies close to Tumba's largest market at Bikoro and had lower values for species number, NPUE, and WPUE than the more distant and protected Mabali.

Effects of season on catch. None of earlier published studies on fish in Lake Tumba presented data from different seasons. The presently reported seasonal data were compared with local knowledge about seasonal effects. Fishing at high water level generally yielded greater WPUE and NPUE than at low water level, which was not expected. Akwah and Yoko (unpublished*) wrote that the dry season is "La grande pêche" (big fishery), as fish are forced out of the previously flooded forests, into the lake, where they are easier to catch. "La petite pêche" (small fishery) occurs during the low water level months. The apparent contradiction with larger catches at high water levels was due to fishing the same sites in the lake during all seasons, whereas local fishers tend to fish in streams and inundated areas during the wet season. The large fluctuation in water level (median annual variation $3.1 \mathrm{~m}$ ) affected the depth for the fishing gear. When nets were set deep some of the largest yields were for species such as Chrysichthys cranchii and $C$. ornatus. This was also reflected in the distribution of WPUE and NPUE as a function of fishing depth (data not shown).

\section{ACKNOWLEDGEMENTS}

The USAID program through its Central Africa Regional Program for the Environment (CARPE) financially supported the fieldwork via WWF. However, views expressed in this paper do not reflect those of the US Government. We are grateful to WWF DRC for providing logistical help. The work was possible thanks to field support by Bosanaga Boss and Ndjombi Papy. We also thank Christian Demandt, Department of Aquatic Sciences and Assessment, Swedish University of Agricultural Sciences (SLU), for analysing the water samples, Sandoka Mola at the Meteorological Service, Centre de Recherche en Écologie et Foresterie de Mabali, for use of the meteorological data and Asad
Jamil, who worked with the satellite images, interpreted by Stefan Hellgren and Andreas Rudh. Mikael Östlund assisted in the preparation of the graphs. We also thank Magnus Appelberg for valuable suggestions to improve the manuscript.

\section{REFERENCES}

Allan J.D., Abell R., Hogan Z., Revenga C., Taylor B.W., Welcomme R.L., Winemiller K. 2005. Overfishing of inland waters. BioScience 55 (12): 1041-1055. DOI: 10.1641/0006-3568(2005)055[1041:OOIW]2.0.CO;2

Anonymous 2006. The forests of the Congo basin. The state of the forest 2006. The Congo Basin Forest Partnership, Kinshasa, DRC.

Anonymous 2019. Lac Télé-Lac Tumba landscape. USAID, Washington DC, USA.

Batzer D.P. 1998. Trophic interactions among detritus, benthic midges, and predatory fish in a freshwater marsh. Ecology 79 (5): 1688-1698. DOI: 10.1890/0012-9658(1998)079[1688:TIADBM]2.0. $\mathrm{CO} ; 2$

Béné C., Brummett R., Bungubetshi G., Gordon A. 2007. Preliminary assessment of Lake Ntomba fisheries. WorldFish Center, Cairo, Egypt.

Boden G., Teugels G.G., Hopkins C.D. 1997. A systematic revision of the large-scaled Marcusenius with description of a new species from Cameroon (Teleostei; Osteoglossomorpha; Mormyridae). Journal of Natural History 31 (11): 1645-1682. DOI: 10.1080/00222939700770881

Brooks E.G.E., Allen D.J., Darwall W.R.T. (Compilers) 2011. The status and distribution of freshwater biodiversity in Central Africa. IUCN, Gland, Switzerland and Cambridge, UK.

Dubois J.Th. 1959. Note sur la chimie des eaux du lac Tumba. Académie Royal de Sciences d'Outre-Mer, Bulletin de Séances 5 (6): 1321-1334.

Froese R., Pauly D. (eds.) 2019. FishBase. [Version 02/2019] http://www.fishbase.org

Froese R., Tsikliras A.C., Stergiou K.I. 2011. Editorial note on weight-length relations of fishes. Acta Ichthyologica et Piscatoria 41 (4): 261-263. DOI: 10.3750/AIP2011.41.4.01

Geerinckx A.D., Adriaens D., Teugels G.G., Verraes W. 2004. A systematic revision of the African catfish genus Parauchenoglanis (Siluriformes: Claroteidae). Journal of Natural History 38 (6): 775-803. DOI: $10.1080 / 0022293021000039160$

Inogwabini B.-I. 2014. Bushmeat, over-fishing and covariates explaining fish abundance declines in the Central Congo Basin. Environmental Biology of Fishes 97 (7): 787-796. DOI: 10.1007/s10641-013-0179-6

Inogwabini B.-I., Mputu D.A., Zanga L. 2009. The use of breeding sites of Tilapia congica (Thys et van Audenaerde 1960) to delineate conservation sites in the Lake Tumba, Democratic Republic of Congo: Toward the conservation of the lake ecosystem. 
African Journal of Ecology 48 (3): 800-806. DOI: 10.1111/j.1365-2028.2009.01180.x

Kalff J.F.J. 2002. Limnology: Inland water ecosystems. Prentice Hall, Upper Saddle River NJ, USA.

Kantoussan J., Ecoutin J.M., Fontenelle G., Thiaw O.T., de Morais L.T., Laë R. 2009. The relevance of size parameters as indicators of fishery exploitation in two west African reservoirs. Aquatic Ecology (2009) 43 (4): 1167-1178. DOI: 10.1007/s10452-009-9236-9

Karlsson J., Byström P., Ask J., Ask P., Persson L., Jansson M. 2009. Light limitation of nutrient-poor lake ecosystems. Nature 460 (7254): 506-509. DOI: 10.1038/nature08179

Kolding J., van Zwieten P.A.M. 2014. Sustainable fishing of inland waters. Journal of Limnology 73 (s1): 132-148. DOI: 10.4081/jlimnol.2014.818

Kutshukina F.L., Micha J.-C. 2013. Analyse des modes d'exploitation des ressources halieutiques du Lac MaiNdombe en République Démocratique du Congo. Geo-Eco-Trop 37 (2): 273-284.

Laë R. 1997. Estimation des rendements de pêche des lacs africains au moyen modèles empirique. Aquatic Living Resources 10 (2): 83-92. DOI: 10.1051/ alr:1997009

Marlier G. 1958. Recherches hydrobiologiques au lac Tumba (Congo Belge, Province de l'Equateur). Hydrobiologia 10 (1): 352-385. DOI: 10.1007/ BF00142195

Matthes H. 1964. Les poissons du lac Tumba et de la région d'Ikela. Étude systématique et écologique. Annales, Sciences Zoologiques No. 126. Musée Royal de l'Afrique central, Tervuren, Belgium.

Milton A.D. 2015. Forest resilience for livelihood and ecosystem services. PhD thesis. George Mason University, Fairfax VA, USA.

Moelants T., Zebe V.M., Snoeks J., Vreven E. 2014. A review of the Distichodus antonii assemblage (Characiformes: Distichodontidae) from the Congo basin. Journal of Natural History 48 (27-28): 27-28. DOI: $10.1080 / 00222933.2013 .862312$

Moreau J., Arrignon J., Jubb R.A. 1988. [Chapitre 19] Les introductions d'espèces étrangères dans les eaux continentales africaines. Intérêt et limites. Pp. 395-425. In: Lévêque C., Bruton M.N., Ssentongo G.W. (eds.) Biologie et écologie des poissons d'eau douce africains. Éditions de l'ORSTOM, Travaux et Documents de l'ORSTOM No. 216.
Norris S.M. 2002. A revision of the African electric catfishes, family Malapteruridae (Teleostei, Siluriformes), with erection of a new genus and descriptions of fourteen new species, and an annotated bibliography. Annales Sciences Zoologiques No. 289. Musée Royal de l'Afrique centrale, Tervuren, Belgium.

Pauly D., Christensen V., Dalsgaard J., Froese R., Torres F.jr. 1998. Fishing down marine food webs. Science 279 (5352): 860-863. DOI: 10.1126/ science.279.5352.860

Poll M. 1942. Les poissons du lac Tumba, Congo Belge. Bulletin du Musée royal d'Histoire naturelle de Belgique 18 (36): 1-25.

Rochet M.-J., Trenkel M.V. 2003. Which community indicators can measure the impact of fishing? A review and proposals. Canadian Journal of Fisheries and Aquatic Sciences 60 (1): 86-99. DOI: 10.1139/f02164

Teugels G.G. 1986. A systematic revision of the African species of the Genus Clarias (Pisces: Clariidae). Annales Musée Royal de l'Afrique Centrale, Sciences Zoologiques 247: 1-199.

Teugels G.G., Denayer B., Legendre M. 1990. A systematic revision of the African catfish genus Heterobranchus Geoffroy-Saint-Hilaire, 1809 (Pisces: Clariidae). Zoological Journal of the Linnean Society 98 (3): 237-257. DOI: 10.1111/j.1096-3642.1990. tb01209.x

Tshibwabwa S.M., Teugels G.G. 1995. Contribution to the systematic revision of the African cyprinid fish genus Labeo: Species from the lower Zaire River system. Journal of Natural History 29 (6): 1543-1579. DOI: $10.1080 / 00222939500770661$

Welcomme R.L. 1988. International introductions of inland aquatic species. FAO Fisheries Technical Paper No. 294. FAO, Rome.

Welcomme R.L. 1999. A review of a model for quantitative evaluation of exploitation levels in multispecies fisheries. Fisheries Management and Ecology 6 (1): 1-19. DOI: 10.1046/j.1365-2400.1999.00137.x

Received: 21 November 2018 Accepted: 4 June 2019

Published electronically: 15 December 2019 